International Journal of Advanced Academic Research (Social and Management Sciences) | ISSN: 2488-9849

Journal DOI: 10.46654/ij.24889849

Vol. 6, Issue 10 (October, 2020)|www.ijaar.org

Article DOI: 10.46654/ij.24889849.s6105

\title{
EFFECT OF ENTREPRENEURIAL SKILLS ON SMALL AND MEDIUM SCALE ENTERPRISES (SMES) PERFORMANCE: A STUDY OF REGISTERED BUSINESSES OPERATING IN SABON GARI MARKET KANO
}

\author{
Muslimu Khamis ${ }^{1}$, Alhassan Musa Gumawa² \\ ${ }^{1}$ Jammaje Academy, Kano State, Nigeria. \\ muslimukhamis@gmail.com \\ ${ }^{2}$ Department of Business Administration and Entrepreneurship, \\ Faculty of Social and Management Sciences, \\ Yusuf Maitama Sule University Kano, Nigeria. \\ alhassangmusa@gmail.com
}

\begin{abstract}
Entrepreneurial skills are a set of specific knowledge, abilities, skills, traits, motives, attitudes and values essential for the personal development and successful participation of each person in an organization. The aim of this study is to investigate the effect of entrepreneurial skills on SMEs performance among owners/managers operating registered businesses in Sabon Gari Market Kano, Nigeria. Descriptive survey research design was used while a sample size of one hundred and seventy two (172) business owners/managers were drawn through the use of Yamane (1967) formula for sample size determination out of three hundred and three (303) owners/managers operating registered businesses in Sabon Gari Market, Kano, which constituted the study population. Probability sampling technique was used which involves simple random sampling. Closed-ended questionnaire served as a data collection tool for the study and Regression analysis was used to analyse the collected data through Statistical Package for Social Science (SPSS) version 21. Face validity and reliability test (Cronbach's Alpha) were conducted. The findings indicate that entrepreneurial skills have significant effect on SMEs performance; it also shows that significant relationship exists between entrepreneurial skills and SMEs performance. The study recommends that business owners and managers should focus on improving entrepreneurship skills in order to improve the performance of small and medium scale enterprises. Future researchers should expand the scope of the study to incorporate more organizations; again the research used only one variable, future researchers should use more variables in order to better capture the opinion of the respondents.
\end{abstract}

Keywords: Entrepreneurial Skills, Small and Medium Enterprises, SMEs Performance 


\section{INTRODUCTION}

Entrepreneurship is recognized as an important driver of economic growth, productivity, innovation and employment, it is widely accepted as a key aspect of economic dynamism transforming business ideas into economic opportunities (Kuratko \& Hodgetts, 2008; Timmons $\&$ Spinneli, 2007). History shows that economic progress has been significantly driven by pragmatic people who are entrepreneurial, innovative, having ability to exploit opportunities and willing to take risks (Hisrich, 2005).

In other words, entrepreneurship is one of the strategies designed to facilitate the participation of certain target groups such as women, youth or disadvantaged groups in the economy. Although many countries regardless of the level of economic development are making serious effort to support entrepreneurship, the impact of entrepreneurship appears to vary. Many times these facts are underestimated by small entrepreneurs and overlooked by support programs for development of this size of entrepreneurship. Development and support programs for Small \& Medium Enterprises (SMEs) should also focus on the area to help develop entrepreneurship skill and knowledge. However, due to lack of comparable result world-wide, there is need to understand how entrepreneurial skill identified elsewhere contributes to performance of SMEs in Nigeria (Gakure, Ngugi, Waititu \& Keraro, 2013).

Entrepreneurial skill is the ability to combine both the innate characteristics and other resources, which depends on the individual's entrepreneurial skills (Moska, 2013). Entrepreneurship is a characteristic embodied in entrepreneurs' mind that help establish businesses, generate employment, create new products and services, stimulate innovation and improve welfare (Souksavanh, 2014). Entrepreneurial skills are the skills, which complement the entrepreneur to analyse situations, opportunities and environments, and assist the entrepreneur/manager to organize/manage and assume the risk and reward of a business or enterprise (Gakure, Ngugi, Waititi, \& Keraro, 2013). According to Afolabi and Macheke (2012), skills essential for the success of SMEs include motivation, ability to gather resources, financial management, human resource management, marketing and technical skills. A weakness in a particular skill is associated with a decrease in the overall performance of the venture.

Skilled entrepreneurs have all it takes to go after their dreams and reach their main goals. They have a way of surviving the tough situation unlike those who have totally no experience or lack important skills such as managerial, accounting, negotiation and customer relationship skills (Wamoto, Ayuma, \& Kimani, 2016). The owner of a business is a key factor in business performance. The relationship between the owner of a business and its performance indicated that entrepreneurial minded owner grow their business to maturity due to their administrative competencies (Sarwoko, Surachman, \& Hadiwidjojo, 2013).

\section{Research Objectives}

The main objective of this study is to investigate the effect of entrepreneurship skills on the performance of small and medium enterprises, while the specific objectives are as follows:

1. To determine the impact of entrepreneurial skills on the performance of SMEs. 
2. To determine the relationship between entrepreneurial skills and the performance of SMEs.

\section{Research Questions}

The research questions are in line with the objectives of the study and they are as follows:

1. Do entrepreneurial skills have effect on the performance of SMEs?

2. Is there any relationship between entrepreneurial skills and performance of SMEs?

\section{LITERATURE REVIEW}

\section{SMEs Performance}

Performance measurement helps an entrepreneur understand, manage and improve his business activities (Pirich, Knuckey, \& Campbell, 2001). Four different approaches are basically used by researchers in measuring performance, namely; goal approach, system resource approach, stakeholders approach and competitive value approach. Phihlela (2012) posited that while the stakeholders and competitive approaches look at meeting the needs and expectations of the external stakeholders, the goal and system approaches focus on meeting the internally-set targets. However, the goal approach is best used when dealing with small businesses due to its simplicity and understandability and targets are set internally based on the owner-managers interest and capability (Taticchi, Botarelli, \& Cagnazzo, 2008).

While Leitão and Franco (2011) contended that financial measures of performance, such as sales and profit, may not clearly reflect the quality of the SMEs' performance. Nevertheless, Chong (2008) asserted that SMEs need to adopt a hybrid approach where the financial and non-financial measures of performance are used against a predetermined goal and time frame. Therefore, combination of these two measures help the owners-managers gain a wider perspective on measuring and comparing their performance in particular, the extent of effectiveness and efficiency in utilizing the resources, competitiveness and readiness to face the growing internal and external pressure.

However, Chong (2008) suggested non-financial measures like increase in the number of employees, growth in market share and customer satisfaction as good indices for measuring SME performance. Kutinisa (2011) opined that profit making, business survival and expansion is the goal of a business, while Ehinomen and Adeleke (2012) suggested performance measurement in terms of increase in profit, branches and employees. Julius (2011) and Jamiya (2010) in their studies on SMEs used changes in sales, profit and assets to measure performance. Appolot (2012) used sales growth, profitability, return on investment and market share as measures of SMEs performance. This explains that most studies on SMEs have used 3 or more performance measurement indices, thus combining the financial and non-financial measures.

\section{Small and Medium Enterprises (SMEs)}

Besides the vast and growing literatures on SMEs, there seems to be no universal definition of the concept (Fatoki, 2011). In a global context, a general definition of SMEs using size and scale 
of operation is not easy, but within fixed co-ordinates of national boundaries, it might be relatively easier (Adebisi \& Gbegi, 2013). Most researchers and policy makers defined it on the basis of total investment, annual sales and number of employees (Kofi, 2014). Generally, the definition is based on either single criterion or a multiple criteria.

In countries like the U.S.A, Britain and Canada, annual turnover and number of paid employees are used as the basis for classification. While India uses total investment, Netherlands, Ghana and Indonesia use number of employees as their criterion (Charles \& Babatunde, 2012). For example, the government of Netherland defines SMEs as businesses employing less than199 persons, while in Indonesia, SMEs are defined as all enterprises, households or cottages employing less than 200 full time workers (Obwori, 2012). The Indian ministry of SME cited in Shastri, Tripathi and Ali (2011) define SMEs in terms of either manufacturing or services. In manufacturing, micro enterprises: those enterprises having a total investment of less than 25lakh (2,500,000), small: Rs 25lakh- Rs 5crore (2,500,000-50,000,000) and medium: Rs 5crore10 crore $(50,000,000-100,000,000)$. In the service sector; micro: annual income of less than 10lakh (1,000,000), small: Rs 10lakh-2crore (1,000,000-20,000,000), and medium: Rs 2crore- Rs 5crore (20,000,000-50,000,000). According to the Regional Project for Enterprise Development (RPED) Ghana, Micro enterprises employ less than 5 employees, Small: 6-29 employees and medium: 30-99 employees (Okoh \& Ping, 2000).

Just like other countries of the world, the definition of SMEs in Nigeria also varies from time to time and between agencies and institutions (Sanni, 2009). In an agreement signed by a committee comprising the Central Bank of Nigeria, Nigerian Industrial Development Bank (NIDB) and the National Council on Industry cited in Charles and Babatunde (2012), SMEs were defined based on the total capital employed (including working capital but excluding cost of land) and number of employees. Micro: having not more than N1, 500,000 and less than 10 workers, Small: N1, 500, 000-N50, 000, 000 and a labour size between 10-35 workers. Medium: N50, 000,000-N100, 000,000 and 35-100 workers. At the 13th Council meeting of the National Council on Industry held in July, 2001, SMEs were redefined by the Council as follows: micro enterprises as those with a labour size of not more than 10 workers, or total asset not more than N1, 500,000 including working capital but excluding cost of land, Small enterprises with a labour size of 11-100 workers or a working capital between N1,500,000-N50,000,000, including working capital but excluding cost of land. Medium Enterprises: with a labour size of between 101-300 workers or a total cost between N50,000,000- N200,000,000, including working capital but excluding cost of land (Adebisi \& Gbegi, 2013). SMEDAN (2012) also adopts dual criteria in defining SMEs in its collaborative study with National Bureau of Statistics. The study define micro enterprises as those employing less than 10 and having total assets of less than N5,000,000, small enterprises as those employing between 10-49 and total asset of N5,000,000N50,000,000 and Medium Enterprises employing between 50-199 and a total asset of N50,000,000-N500,000,000.

Based on the preceding review, it is worth deducing that the Nigerian classifications of SMEs are basically in three dimensions i.e. in terms of capital employed or the number of employees or a combination of both. Since there is no uniformity in the various definitions, the study adopts the SMEDAN definition because it is more recent. 


\section{Entrepreneurs skills}

Entrepreneurial skills are needed by managers for the development and running of their businesses (Papulová, 2007). The concept of entrepreneurial skills has been defined by Reza, Javadin, Amin, Tehrani and Ramezani (2010) as specialized technical knowledge that entrepreneurs should possess in order to perform their roles and these skills are acquired through learning and experience. Spencer and Spencer (1993) define entrepreneurial skills as underlying characteristics of an individual that are casually related to effective and/or superior performance in a job or situation. Kaur and Bains (2013) similarly defined it as the individual characteristics of a person who undertakes risk for gaining profit in the business venture. Underlying characteristic means the skills are a fairly deep and enduring part of a person's personality and can predict behavior in a wide variety of situations and job tasks.

Other researchers view entrepreneurial skills as constituting more than just personality traits but have to be shown in the entrepreneur's behaviour while managing his business. In the light of this, Martina, Hana and Jiří (2012) defined entrepreneurial skills as a set of specific knowledge, abilities, skills, traits, motives, attitudes and values essential for the personal development and successful participation of each person in an organization. Rezaei-Zadeh, Hogan, O'Reilly, Cleary and Murphy (2014) defined it as the abilities of the person that enable him/her to demonstrate the appropriate entrepreneurial behaviour including: identifying opportunities, startup and maintenance of business. Sanda (2011) also refers to it as specific behaviour and characteristics of a person that result in effective or superior performance.

Fizel and Itri (2014) identified 4 skills needed in Nigerian Firms, namely: Individual skills, Supervisory skills, line management skills and strategic skills. This view looks at large organizations having different levels of management where a manager at each level is expected to possess a specific skill. Lowden (1988) in his study titled "managerial skills for the entrepreneur" came up with four areas an entrepreneur needs to develop in order to be a strong and successful manager; they include planning, organizing, leading and controlling. He concludes that an entrepreneur needs to have the following skills; planning skills; deals with establishing goals and ways of achieving it, organizing skills; arranging work and people to accomplish set objectives, controlling skills; making sure that performance conform with plans and leading skills; encouraging the human factor in performance.

Based on the above review, we can conclude that entrepreneurial skills and managerial skills are ambiguously used interchangeably, but others cover similar skills but different terms to describe them and there is no absolute set of skills for each of them. However, From the preceding review, it is worth deducing that entrepreneurial competencies generally comprise of those that are deep rooted in a person's background (including entrepreneurial characteristics, traits, and personality), those that serve as unconscious thought of the entrepreneur (motives) and those that are acquired at work through training (knowledge, experience and skills) (Lowden, 1988).

\section{THEORETICAL FRAMEWORK}

The theoretical framework is developed in line with the evidence available. Figure 1.1 establishes the effect of independent variable on the dependent variable. 


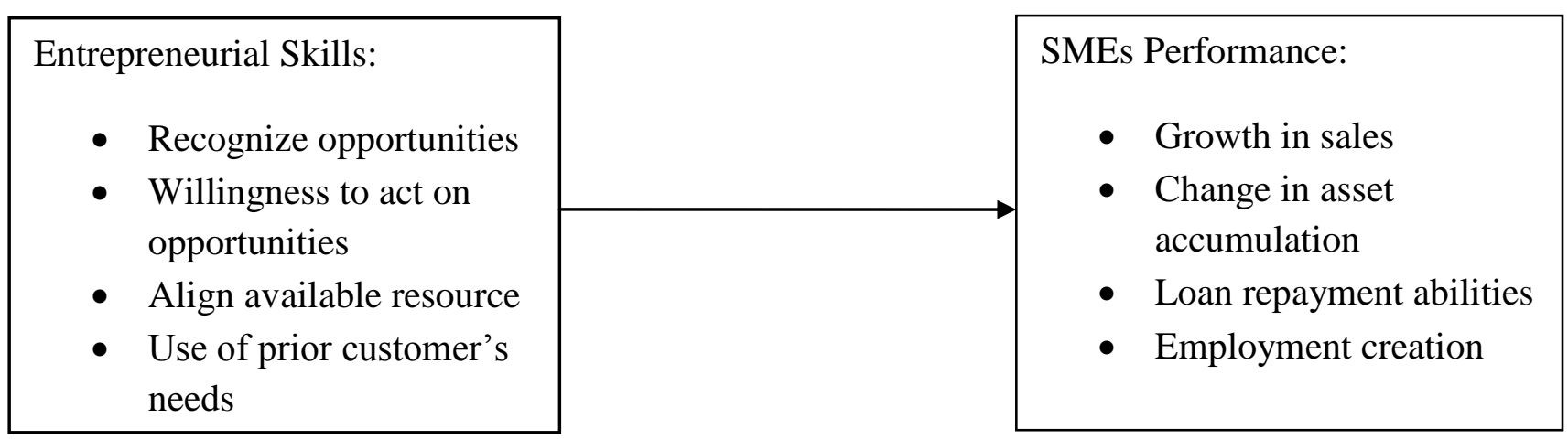

Figure 1.1 Theoretical Framework

\section{HYPOTHESES DEVELOPMENT}

\section{Effect of Entrepreneurial Skills on SMEs Performance}

Empirical studies conducted by different scholars revealed that entrepreneurial skills do affect performance of small and medium enterprises (SMEs). However researchers such as Kinyua (2014), Mohammed \& Obeleagu-nzelibe (2014), Thandeka (2008) \& Tijjani (2012) found that entrepreneurial skills have positive and significant effect on SMEs performance and it is one of the key success factors of SMEs. While researchers such as (Ali \& Mohammed, 2017) found a negative effect of entrepreneurial skills on SMEs performance.

Below is the hypothesis formulated based on the above argument.

H1: Entrepreneurial skills have positive and significant effect on SMEs performance.

\section{Relationship between Entrepreneurial Skills and SMEs Performance}

Empirical studies carried out by some researchers also found a positive and significant relationship between entrepreneurial skills and SMEs performance, scholars such as (Macheke, 2012; Kinyua, 2014; Mohammed \& Obeleagu-nzelibe, 2014 \&Thandeka, 2008) found positive and significant relationship between entrepreneurial skills and SMEs performance. While Ali \& Mohammed (2017) and Tijjani (2014) found an inverse relationship between the study variables.

Below is the hypothesis formulated based on the above argument.

H2: There is positive and significant relationship between entrepreneurial skills and SMEs performance.

\section{METHODOLOGY}

The aim of this study is to investigate the effect of entrepreneurial skills on SMEs performance among owners/managers operating registered businesses in Sabon Gari Market Kano, Nigeria. A sample size of one hundred and seventy two (172) business owners/managers was drawn through the use of Yamane (1967) formula for sample size determination out of three hundred and three (303) owners/managers operating registered businesses in Sabon Gari Market, Kano, which 
constituted the study population. A closed-ended questionnaire was developed using five Likert Scale, the questionnaires were distributed to one hundred and seventy two (172) business owners/managers operating registered businesses in Sabon Gari Market, Kano. Out of the questionnaires distributed only 158 respondents responded to the questionnaires that were used in the analysis of this study. The questionnaire was divided into two parts. Part one comprises of the demographic profile of the respondents. Part two includes items on the research constructs which include: SMEs Performance and Entrepreneurial Skills. Reliability test was conducted and face validity was also used in the study. Regression Analysis was used to test the hypothesis under study using Statistical Package for Social Science (SPSS) software version 21.

\section{VALIDITY AND RELIABILITY}

Reliability and validity were used in the study; validity is the degree to which an instrument measures what it is supposed to measure. Expert opinion, comment from colleagues and supervisor, and backing up the items developed through literature help in ensuring validity (Kothari, 2004). Face validity was used in the study and in face validity, the researcher seeks to examine whether the instrument measures the main concept of the research or not (Litwin, 1995). Reliability on the other hand, is a measure of the degree to which a research instrument yields consistent results or data after repeated trial (Bell, 1993). This study used internal consistency for measuring reliability of data. Cronbachs' Alpha Coefficient is the most important measure of internal consistency that refers to the degree in which the questions of the questionnaire measure the variables or characteristics (John \& Reve, 1982).

In general, a Cronbach alpha of 0.6 has been accepted as the minimum benchmark for examining reliability of this study. The reliability test of this study presents its findings based on each construct of the study comprising of entrepreneurial skills and SMEs performance, therefore, the results of the reliability test show that, the Cronbach alpha for the variables under study reached acceptable reliability coefficient which is within the acceptable range of 0.6 and above, all the constructs show high internal consistency, and the items loading in all the constructs are above 0.60. The Cronbach's Alpha value for entrepreneurial skill is 0.926 and the Cronbach's Alpha value for SMEs performance is 0.903 . From the above results and analysis, it clearly shows that the items on each construct of the pilot study were reliable and recommended for analysis.

\section{RESULTS AND DISCUSSIONS}

\section{Response Rate}

Table 4.2 describes the finding of this study in respect of the response rates of the respondents. The result indicates that out of one hundred and seventy two (172) copies of the questionnaire distributed which represent (100\%), a total of (158) respondents representing (91.9\%) sourced from owners and managers operating registered businesses in Sabon Gari Market Kano, Nigeria have filled and returned the questionnaires. However, a total of fourteen (14) questionnaires representing $(8.1 \%)$ were not returned. 
Table 4.2 Frequency of Response Rate

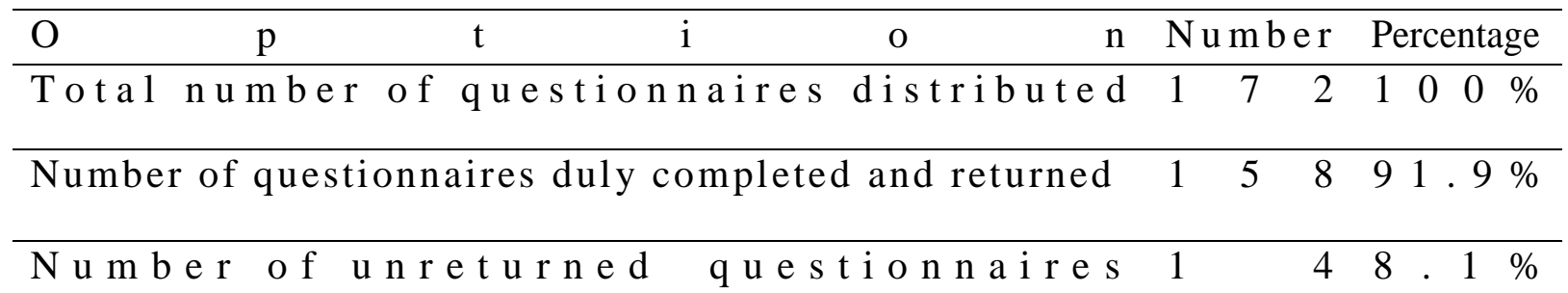

\section{Source: survey data (2020)}

A total of 158 respondents constitute the sample of this study, which shows a good response rate of $(91.9 \%)$ that covers a wide range of owners and managers who operate different registered businesses in Sabon Gari Market Kano, Nigeria. This rate is considered sufficient according to Sekaran (2003) who argues that response rate of $30 \%$ is acceptable for surveys.

\section{Test of Hypothesis}

Multiple regression analysis was used to assess the effect of independent variables on dependent variable of the study. The result was presented in accordance with the objectives stated earlier in the study. The results of the hypothesis testing are summarized. The standardized path coefficient indicates whether the direction of the relationship is either positive or negative while the t-value assesses whether this relationship is significant or not (Ho, 2006; Hair et al., 2006 \& Zainudin, 2014).

SMEs performance serves as the dependent variable while entrepreneurship skills serve as the independent variables. The result from the regression equation shows that F-value of 99.193 is significant at $<0.000$ level whereby it is less than alpha value 0.05 that represents the focused model and it best described the relation between the independent variable and the dependent variable. The absolute value of the correlation coefficient between entrepreneurship skills and SMEs performance is 0.812 , this indicates the strength of the relationships. The $\mathrm{R}$ squared of .659 or $65.9 \%$ is the proportion of variation in the dependent variable SMEs performance, as explained by the regression model. The values of $\mathrm{R}$ squared range from 0 to 1 . In this case, the $\mathrm{R}$ squared value of 0.659 or $65.9 \%$ is moderate, which means that the model fits the data well. The adjusted $\mathrm{R}$ squared is known as the coefficient of determination and it tells the variation in dependent variable due to changes in independent variable, the adjusted $\mathrm{R}$ squared was 0.652 which tells that there was $65.2 \%$ variation in SMEs performance due to changes in entrepreneurship skills, see tables 4.4 and 4.5 below. 
performance. This study has highlighted dimensions of entrepreneurship skills as important factor which can contribute towards SMEs performance. The results of this study revealed that entrepreneurship skill has significant effect on SMEs performance; this implies that business owners that have more entrepreneurship skills are more likely to have more performing business organization, in addition it demonstrates that increase in entrepreneurship skills will lead to increase in organizational performance.

The matters introduced in the introduction of this study regarding entrepreneurship skills nowadays were partially found in this study as well. SMEs performance is very important for them. If the businesses try improving SMEs performance by focusing on development of entrepreneurship skills, entrepreneurship has a very important position in the hastily changing socio-economic scenario in the world, and entrepreneurs play an important role in assisting the development of nation as they will help to reduce the unemployment rate.

\section{Recommendation and Suggestion for Future Research}

It is therefore recommended that business owners and managers should focus on improving entrepreneurship skills in order to improve the performance of small and medium scale enterprises thereby helping in economic growth and unemployment reduction as well as wealth maximisation.

This research is very limited in scope, future researchers should expand the scope of the study to incorporate more organizations, again the research used only one variable, future researchers should use more variables in order to better capture the opinion of the respondents. 


\section{REFERENCES}

Abubakar, H, H. (2014). Entrepreneurial characteristics and the growth of small scale businesses in Zaria Metropolis. (An Unpublished Master's Thesis). Ahmadu Bello University Zaria, Nigeria.

Adebisi, J. ., \& Gbegi, D. O. (2013). Effect of multiple taxation on the performance of small and medium scale business enterprises. (A Study of West African Ceremics Ajeokuta, Kogi State). Mediterranean Journal of Social Sciences, 4(6), 323-334.

Brady, C., Dale, M., Iles, P., Cliffs, E., \& Hall, N. J. P. (2007). Managerial skills. Journal of Business Management and Economics, 2(1), 1-8.

Charles, A., \& Babatunde, H. (2012). An evaluation of the challenges and prospects of micro and small scale enterprises development in Nigeria. American International Journal of Contemporary Research, 2(4), 174-185.

Cooney, T.M.(2013) Entrepreneurial skills for growth oriented business. Retrieved from http://www.oecd.org/cfe/leed/cooney_Entrepreneurship_Skills_HGF.Pdf.

Cooper, D.R. \& Schindler, P.S. (2003). Business research methods. New York: McGraw-Hill.

Dingee, A. L. M., Haslett, B., \& Smollen, L. E. (1970). Characteristics of a successful entrepreneurial management team. Journal of Business Management \& Social Sciences Research, 10(4), 50-62.

Driessen, M. P., \& Zwart, P. S. (2000). The entrepreneur scan measuring characteristics and traits of entrepreneurs. Retrieved from http://www.entrepreneurscan.co.uk/wpcontent/uploads/2010/10/E-Scan-MAB-Article-UK.pdf

Fatoki, O. (2014). The Impact of managerial competencies on the performance of immigrantowned enterprises in South Africa. Mediterranean Journal of Social Sciences, 5(6), 141144.

Fatoki, O. O. (2011). The impact of human, social and financial capital on the performance of small and medium-sized enterprises (SMEs) in South Africa. Mediterranean Journal of Social Sciences, 29(3), 193-204. 
Farris, P. W., Bendle, N. T., Pfeifer, P. E., Reibstein, D. J. (2010). Marketing metrics: The definitive guide to measuring marketing performance. Upper Saddle River, New Jersey: Person Education, Inc.

Fazli, M., Muhammed, S., \& Yasuo, H.,(2013). Sales growth, profitability and performance: empirical study of Japanese ICT industries with Three Asian Countries. Journal of Contemporary Research in Business. 4(11), 1-19.

Fizel, J. L., \& Itri, M. P. D. (2014). Managerial efficiency, managerial succession organizational performance. Journal of Business Management \& Social Sciences Research, 18(4), 295308.

Hair, J., Black, W. C., Babin, B. J., \& Anderson, R. E. (2010). Multivariate data analysis (7th ed.). Upper Saddle River, New Jersey: Pearson Education International.

Israel, G. D. (2013). Determining sample size 1. Journal of Business Research, 1(1), 1-5.

Jamiya, N. (2010). Managerial competencies, access to credit and business success. (An Unpublished Masters Thesis). Makerere University, Kampala, Uganda.

Joseph, O. (2010). Entrepreneurial psychological traits and performance:implication for Nigerian Non-Oil SMEs exporting companies. Review of Economics and Business Studies, (6), 211-220.

Kaur, H., \& Bains, A. (2013). Understanding the concept Of entrepreneur competency. Journal of Business Management \& Social Sciences Research (JBM\&SSR), 2(11), 31-33.

Kaplan, R. S. \& Norton, D.P (1996). Using the balanced scorecard as a strategic management system. Harvard Business Review, 74(1), 75-85.

Khang, T. N. (2012). Training managerial skills for first line managers. (An Unpublished Undergraduate Project). Mikkeli University of Applied Science, Finland.

Kinyua, A. N. (2014). Factors affecting the performance of small and medium enterprises in the Jua Kali Sector In Nakuru Town, Kenya. IOSR Journal of Business and Management, $16(1), 80-93$.

Kochadai, M. (2012). The concept of entrepreneurial competency, competency model and review of earlier studies. In Entrepreneurship (pp. 23-58). Greenwood Press. 
Kofi, M. E. (2014). Assessing financial reporting practices among small scale enterprises in Kumasi Metropolitan Assembly. European Journal of Business and Social Science, 2(10), 81-96

Krishna, S. M. (2013). Entrepreneurial motivation: A case study of small scale entrepreneurs In Mekelle. Journal of Business Management \& Social Sciences Research (JBM\&SSR), 2(1), 1-6.

Macheke, R. (2012). An analysis of entrepreneurial and business skills and training needs in SMEs in the plastic manufacturing industry in the Eastern Cape Province, South Africa. International Review of Social Sciences and Humanities, 3(2), 236-247.

Machirori, T., \& Fatoki, O. (2013). The impact of firm and entrepreneur's characteristics on networking by SMEs in South Africa. Journal of Economics, 4(2), 113-120.

Martey, E., Annin, K., Attoh, C., Wiredu, A. N., Etwire, P. M., \& Al-Hassan, R. M. (2013). Performance and constraints of small scale enterprises in the Accra Metropolitan Area of Ghana. European Journal of Business and Management, 5(4), 83-93.

Martina, K., Hana, U., \& Jiří, F. (2012). Identification of managerial competencies. Journal of Competitiveness, 4(1), 129-142.

Mitchelmore, S., \& Rowley, J. (2010). Entrepreneurial competencies: a Literature Review and development agenda. International Journal of Entrepreneurial Behaviour \& Research, 2(2), 16-25.

Mohammed, U. D., \& Obeleagu-nzelibe, C. G. (2014). Entrepreneurial skills and profitability of small and medium enterprises (SMEs): resource acquisition strategies for new ventures in Nigeria. 25th International Business Research Conference, 1-21.

Mokaya, S. O. (2012). The concept of entrepreneurship ; in pursuit of a universally acceptable definition. Journal of Entrepreneurship, 1(6), 128-135.

Morgeson, F. V., \& Petrescu, C. (2011). "Do they all perform alike?" An examination of perceived performance, citizen satisfaction and trust with US federal agencies. international review of administrative sciences, 77(3), 451-479.

NEDEP. (2011). A new way of delivering enterprise development and building an enterprise nation. Nigeria. 
Obwori, E. (2012). The effect of funding constraints on the growth of small scale enterprises in soapstone industry of Kenya . International Journal of Arts and Commerce, 1(6), 111127.

OECD (1992), Adult Illiteracy and Economic Performance, Paris: OECD.

Ogechukwu, A. D. (2011). The role of small scale industry in national development in Nigeria. historical development and orientation of small scale industry. Universal Journal of Management and Social Sciences, 1(1), 23-41.

Ogunleye, A. J. (2012). Self esteem and achievement motivation : economic growth and development. Research Journal in Organizational Psychology \& Educational Studies, l(3), 145-148.

Okoh, G. A., \& Ping, G. (2000). Financing small-scale manufacturing firms In Ghana. International Journal of Arts and Commerce, 2(3), 23-30.

Pallant, J., \& John, S. (2005). SPSS Survival Manual. Open University Press. Philadelphia.

Phillips, J. J. (1997). In action: measuring return on investment, Alexandria, Virginia: American Society for Training and Development.

Phihlela, T. R. (2012). A measurement framework to assess SME performance. Information Systems Educators Conference (pp. 1-9). New Orleans Louisiana, USA.

Pirich, A., Knuckey, S., \& Campbell, J. (2001). An interface between entrepreneurship and innovation: New Zealand SMEs Perspective. DRUID Nelon \& Winter Conference.

Rao, V., Joshi, H. G., \& Nadu, T. (2013). A Study on Entrepreneurial Characteristics and Success of Women Entrepreneurs Operating Fashion and Apparel Business. Asian Journal of Management Sciences and Education, 2(2), 1-12.

Reza, S., Javadin, S., Amin, F., Tehrani, M., \& Ramezani, A. (2010). Studying the Relationship Between Managerial Skills and Efficiency of Bank Branches. International Journal of Business and Management, 11(2), 170-177.

Rezaei-Zadeh, M., Hogan, M., O’Reilly, J., Cleary, B., \& Murphy, E. (2014). Using Interactive Management to Identify, Rank and Model Entrepreneurial Competencies as Universities' Entrepreneurship Curricula. Journal of Entrepreneurship, 23(1), 57-94. 
Sanda, A. (2011). Managerial Competence and Non-Performance of Small Firms in a Developing Economy. Interdisciplinary Journal of Contemporary Business Studies, 2(3), 6-24.

Sanni, O. O. (2009). Small Scale Industry : Problems of Establishing Small Business Enterprise in Nigeria Case Study : Alahteef Nigeria. Journal of Business Economics, 2(4), 43-50.

Segal, G., Borgia, D., \& Schoenfeld, J. (2005). The Motivation to become an Entrepreneur. International Journal of Entrepreneurial Behaviour \& Research, 11(1), 42-57.

Shastri, R. K., Tripathi, R., \& Ali, M. (2011). Liberalization and its Impact on Small Scale Industries. International Journal of Vocational and Technical Education, 2(7), 81-83.

Smedan. (2012). Survey Report on Micro, Samll and Medium Enterprises (MSMEs) in Nigeria. National Bureau of Statistics. Nigeria.

Spanos, Y. and Lioukas, S. (2001). An examination into the causal logic of rent generation: Contrasting Porter's competitive strategy framework and the resource-based perspective. Strategic Management Journal, 22(10), 907-934.

Spencer, L. M., \& Spencer, S. M. (1993). Competence at Work: Model for Superior Performance. Human Resource Development Quarterly, 5(4), 361-395.

Tagrafa, H., \& Akinb, E. (2009). Relations Between the Characteristics of Entrepreneurship and the Business Owner : An Analysis of Sme's in Konya. Journal of Business Management \& Social Sciences Research, 4(2), 239-257.

Thomas, W. Y. (2008). Entrepreneurial Competencies and the Performance of Small and Medium Enterprises: An Investigation through a Framework of Competitiveness. Journal of Small Business and Entrepreneurship, 21(3): 257.

Van der Laan, R., Driessen, M., \& Zwart, P. (2010). Entrepreneur Scan Identifies Potential Fast Growers, 1-16. 